\title{
Waste Pickers in the Informal Economy of the Global South: Included or Excluded?
}

Bisschop, L. \& Coletto, D. ${ }^{1}$ (accepted). Waste Pickers in the Informal Economy of the Global South: Included or Excluded? International Journal of Sociology and Social Policy.

\section{Abstract}

Purpose: This article aims to provide insights into the role and practices of informal waste pickers and the implications for waste management policy in urban contexts of the Global South.

Design/methodology/approach: A qualitative case study was used, including interviews, observations and document analyses. We compared informal waste management in two cities of the Global South: Accra (Ghana) and Porto Alegre (Brazil).

Findings: The analysis points out that informal waste pickers play a crucial role in the implementation of waste policies in both cities, despite differing economic, social and institutional contexts. The study of the waste management system also points to multiple connections between informal and formal parts of the economy. Although the informal waste pickers are integral to the waste management system, their economically disadvantaged position excludes them from the formal labour market. Faced with these challenges, they develop creative solutions to guarantee their livelihood and gain collective voice.

Research limitations: The comparison of two case studies, conducted about the same social phenomenon in two different economic, institutional and social contexts, has limited generalizability but is theoretically and practically important.

Practical implications: The findings are relevant to policy-makers who deal with urban waste management and for organizations who develop support actions for informal workers.

Originality/value: We draw on a comparison of qualitative case studies to explore the multidimensionality of the waste picker's phenomenon. This article sparks discussion among scholars

\footnotetext{
${ }^{1}$ Both authors contributed equally to this article.
} 
and experts who study the informal economy from different perspectives, in this case bridging insights from sociology and victimology.

Key words: Informal economy; waste management; victimology; Brazil; Ghana.

Article classification: Research paper.

\section{Introduction}

Informal employment has increased in many parts of the world and it remains an important source of income in developing countries (Chen, 2006; Kanbur, 2015; ILO, 2007; OECD, 2009; Schneider et al., 2010). Working in the informal economy is often the only available source of livelihood. Various informal workers operate in the streets, satisfying the demand for goods and services of an increasingly large population of low and medium-to-low income earners who live in the cities of the Global South. Due to economic globalization, more processes of production and exchange of goods and services have been included in the informal economy, fostering an 'informalization' process that has reconfigured the economic dynamics of many cities (Sassen, 2007).

Over the years various scholars have pointed out the difficulties of clearly and universally defining the conceptual boundaries of the informal economy (Godfrey, 2011; Hart, 2010). Despite these difficulties, the literature on the informal economy is growing. In recent years, scholars have stressed the importance of gaining insights on the nature of the informal economy and on how it interacts with government interventions in terms of taxes, law enforcement and welfare (Gasparini and Tornarolli, 2006; Godfrey, 2015; La Porta and Shleifer, 2014; Schneider and Enste, 2000; Williams, 2014; Williams Horodnic and Windebank, 2015). Most of these studies focused on macro-level factors, providing limited information about how the 'unregulated' part of the economy works on a daily basis, about which social practices allow informality to emerge and grow, and about the interaction between 'unregulated' and regulated parts of the 'substantive' economy (Polanyi, 1977).

The increasing volume of waste generated globally is one of the most prominent environmental issues the world faces. Global municipal waste generation is currently at an estimated 1.3 billion tonnes per year and is expected to increase to 2.2 billion by 2025 and to 13.1 billion by 2050 (Baker et 
al., 2004; Hoornweg and Bhada-Tata, 2012). This increased generation of solid waste is a particular challenge for the Global South due to its rapid urbanization and industrialization (Portes and Schauffler, 1993). Many developing countries and economies in transition lack the infrastructure to deal with waste, even the non-hazardous fractions. Usually, the responsibility for waste management lies with local authorities (mainly municipalities) while the work of the informal waste pickers is described as 'poor and unregulated' and as something that is counterproductive to effective urban waste collection and recycling (Sassen, 2014). This dichotomous view does not correspond with the complex reality of waste management in the Global South. Informal waste workers are economically and socially excluded from the formal labour market, but they are, at the same time, integral to the implementation process of the recent and important environmental policy of urban waste management. Therefore, this article analyses the roles and activities of these waste pickers in the 'unregulated' part of the urban economy and into their relations with formal economic actors, citizens and institutions.

\section{Method}

This article uses findings of two case studies concerning waste management and waste pickers in two different urban contexts of the Global South. Case studies often contain a substantial element of narrative and good narratives typically approach the complexities and contradictions of real life (Barley and Kunda, 2001; Flyvbjerg, 2006; Peattie, 2001; Van Maanen, 1979). The case study method can contribute to the cumulative development of knowledge but the findings generated are often limited to the geographical context in which the study was conducted. There are various ethnographic studies on the informal economy in general and on waste pickers in particular (Calafate-Faria, 2013; Rosaldo, 2012; Thieme, 2013). However, attempts to compare and discuss multiple case studies are rare. Therefore, this article reports about a dialogue between two single case studies concerning (informal) waste management and waste pickers. In this way, we aim to broaden the debate and develop a multi-local and multi-disciplinary perspective on the role and social practices of informal waste pickers of the Global South. We hope this comparison can be an initial step to define and 
understand - also at micro-level - global processes that characterise phenomena such as the informal economy.

The two cases of Porto Alegre (Brazil) and Accra (Ghana) have various features in common, even though they were not included in the same research project and were conducted by different researchers in diverse years. Both studies started from the assumption that in order to truly understand the social practices that characterise the informal economy and its interaction with the formal economy, it is important to 'follow the people' and, in many cases, to 'follow the things' (Schmoll and Semi, 2013). Therefore, they use qualitative research tools and specifically ethnographic observations of the work and working circumstances of waste pickers, non-structured interviews with waste pickers and semi-structured interviews with waste management associations, government representatives and NGO representatives. The case studies also included the analysis of documents about waste management, urban development and environmental policy.

The Porto Alegre case study included participant observation in the waste pickers association Novo Cidadão. The fieldwork lasted about seven months (May-November 2004) during which periods of work in the association alternated with periods of research activities focused on other social actors directly or indirectly involved in urban waste management. Interviews with members of the waste pickers association took place spontaneously during the observation $(\mathrm{N}=15)$. In addition, semistructured interviews were done with members of Centro de Educação Ambiental (CEA) association and of other waste pickers' associations operating in Porto Alegre $(\mathrm{N}=10)$, own-account waste pickers $(\mathrm{N}=10)$, representatives of Municipal Waste Management Department and of Municipal Urban Planning Department, and representatives of NGOs that operated in the MSW management field $(\mathrm{N}=8)$. A few members of NGOs have been contacted more recently in order to update some information on the urban waste management in Porto Alegre. Finally, during the fieldwork, various meetings of waste pickers were attended.

The Accra case study is based on a literature review, document analysis, non-structured interviews with waste pickers $(\mathrm{N}=11)$, semi-structured interviews with relevant government agencies, non-governmental organizations and formal waste companies $(\mathrm{N}=6)$ and more limited participant 
observation. The non-structured interviews with waste pickers occurred during visits to the dumpsite Agbogbloshie in Accra and during an e-waste dismantling workshop organized by a local NGO. The participant observation took place in March 2012 and included the Agbogbloshie dumpsite, the port of Accra where waste shipments are inspected upon entry into the country and a training program that aims to instruct informal e-waste workers on better dismantling technique. In this way, the analysis paid attention to the main actors involved in waste management as well as to the role of informal workers in society as 'victims', 'offenders' and 'social problems'. The case analysed the role of waste pickers related to waste from electronic and electrical equipment, resulting from both domestic consumption and (illegally) imported waste shipments (from the EU or US).

The comparison thus included two case studies about the same social phenomenon in two different economic, institutional and social contexts. It has limited generalizability, but is theoretically and practically important. Theoretically, it aims to spark discussion among scholars and experts who study the informal economy from different perspectives, in this case bridging insights from sociology and victimology. Practically, it facilitates reflection on the implications of informal waste management for policy-makers on matters of waste management, environmental policy, labour and the informal economy.

\section{Understanding the informal economy}

Over the last 50 years, informality has grown in different regions of the world and specifically the Global South has the majority of its workforce employed in the informal economy (Bacchetta, Ekkehard and Bustanabte, 2009; Charmes, 2012; ILO, 2002; OECD, 2009). The informal economy has been an object of study since the beginning of 1970s when economic anthropologist Keith Hart published the first ethnographic study on the informal economy in Accra (1973).

Basically the informal economy includes 'all income-earning activities that are not regulated by the state in social environments where similar activities are regulated' (Castells and Portes, 1989, p. 12). Formality is thus grounded in and sheltered by the formal institutional matrix of a larger social unit like a nation state (Godfrey, 2015). Informality is composed of economic activities that are not, 
but are supposed to be, declared to the state for tax, social security and labour law purposes (Williams et al., 2013). Moreover some studies have defined sub-categories of informality in terms of basic features of units of production, average earnings, employment status (self-employment, wage employment), aims (for profit, not for profit) and social welfare coverage (Feige, 1990; GuhaKhasnobis et al., 2006; Hart, 2010; ILO, 1972, 2002, 2015; Williams et al., 2015). The relationship with the state and its regulatory system is therefore the basis for defining and analysing informality. Usually, this interaction manifests itself as a conflict in which the 'unregulated' part of the substantive economy is essentially viewed by the state, or local authorities, as a phenomenon to be fought and reduced (Centeno and Portes, 2006).

Throughout the years, economy, sociology and anthropology have focused on specific features of the informal economy, sharpening their disciplinary specialization and weakening the dialogue between different approaches to informality. Dialogue within disciplines has even proven to be difficult because different research methods highlight different features of the informal economy, creating diverse interpretations of the phenomenon (Godfrey, 2011).

Three perspectives have dominated the discussion: the dualist, structuralist and legalist schools of thought (Portes, Castells and Benton, 1989; Rakowski, 1994). These approaches to informality are based on a series of dichotomies such as formal-informal, legal-illegal, traditional-modern and marketstate. First, the dualist perspective perceives informal workers as marginal workers who - for whatever reason - failed to get a 'good' job in the formal economy and were therefore forced into 'bad' jobs of the informal economy. This informal economy essentially represents economic activities and forms of employment that were typical for pre-modern societies (Lewis, 1954). Second, within the structuralist perspective the informal economy basically represents various forms of waged employment, which are at the bottom of the employment hierarchy and thus characterized by low wages and poor working conditions (Castells and Portes, 1989; Gallin, 2001; Latouche, 1993). These people are excluded from state benefits and the formal labour market, constituting a segment of the workforce subordinated and functional to the currently prevalent model of capitalism. Consequently informal workers are considered to be victims of modernization and globalization processes. Thirdly, the legalist approach 
sees the informal economy as a form of rebellion in reaction to the excessive and ineffective role of the state in the economy (De Soto, 1989). In this view, informal workers are mainly considered as own-account workers who voluntarily and rationally decide to 'exit' the formal economy.

In order to go beyond the dichotomies that characterise these perspectives, more recent studies have tried to define various forms of informality along the formal-informal continuum. They have focused their attention on how the characteristics of informality are influenced by governmental regulation of labour markets, taxes and social welfare (Agarwala, 2013; Chen, 2006; Williams et al., 2015). These studies have contributed to the knowledge about informality and its functions, but theoretical and empirical attention has often remained at macro-level, leaving the analysis within the 'box' of unregulated economic activities and labour (micro-level) fairly unexplored. Recently some researchers have tried to fill this gap. For instance in-depth studies of informal waste management (Thieme, 2015), as well as sex work (Mahdavi, 2013), have revealed that local and global elements, both individually and in interaction, determine the often very conscious choice to work in the informal economy. This has allowed demystifying common assumptions about informal work being merely a result of deprivation, a lack of formal working opportunities or inadequate planning. Sometimes the informal economy provides more autonomy, economic flexibility and sustainable livelihood because it better appreciates the resourcefulness, adaptability and entrepreneurship of the urban poor (Thieme, 2010). This article contributes to this growing body of research on micro-dimensions of informality, while not ignoring the macro dynamics that influence the phenomenon. We do so by analysing the work practices that characterize a typical example of informality in the South of the world: waste pickers and their interaction with the formal economy.

\section{Urbanization, globalization and waste management}

The management of waste, both urban and industrial, became increasingly problematic with the advance of urbanization, the invention of increasingly resistant materials, and the profound changes in lifestyles. Today, about half of the world population lives in cities and various estimates forecast that it will increase to over two thirds by 2050 (Scott, 2012). A rising population, consumption and 
production all contribute to the increase in waste. Waste management has become a defining element for the urban liveability of the Global North and South. In the Global North, the increasingly rigorous waste legislation led to higher prices for environmentally-sound waste management, with people becoming warier of waste landfills, no longer wanting the waste 'in their own backyard'. Moreover the use of synthetic and chemical products has increased, with e-waste (waste from electronic and electrical equipment) as one of the most prominent in both quantity and toxicity (Pellow, 2007). This goes hand in hand with the increased trade in waste destined for recovery, treatment or disposal, domestically, within regions and between the Global North and South (Lundgren, 2012; UNODC, 2009).

Waste has become a very visible aspect of urbanization and economic development (e.g. increased consumption) in the Global South. Beyond the management of waste imported from abroad, developing countries are also producers of waste, which is usually managed with little technical capacity and inadequate resources (United Nations Human Settlements Programme 2010). Open dumping and burning of waste is commonly practised across regions, leading to a range of environmental and public health problems (Wilson et al., 2012). The environmental, economic and social aspects of waste management represent a big challenge for national and local authorities in many less economically developed countries (Harsch, 2001). Waste remains a threat to environmental and public health as well as an economic and environmental opportunity (Thieme, 2013).

\section{Waste management and waste pickers}

Besides containing hazardous substances (Robinson, 2009), waste also consists of materials that are valuable and that can be recycled (Wong, 2015). In many cities of the Global South, the 'revalorization' of waste is mainly done by the work of informal waste pickers. An estimated 15 million people work in informal waste management, picking recyclable and reusable materials from mixed garbage, independent from formal waste management (Medina, 2007). Waste pickers collect garbage from public and private buildings, separating recyclable items (paper, cardboard, aluminium, glass, parts of e-waste, and different types of plastic) from the material destined for the rubbish dumps 
(organic waste and non-recyclable refuse). They transport them in heavy handcarts, sacks or horsedrawn wagons to sell at depots. For them, waste is their main source of livelihood. Informal waste management is also a service provided to the community in the absence of an effectively organized formal waste management system (Prahalad and Hammond, 2002; Thieme, 2010). Informal workers see waste as an opportunity for a source of income in the gap left by the state. Waste business is then less stigmatized as a job of last resort and instead recognized as a source of economic opportunity for the urban poor (Thieme, 2013).

Waste pickers are often perceived as either victims or perpetrators. On the one hand, they are seen as victims, who are subject to social stigma and mainly belong to socially vulnerable groups, such as migrants, women, children, the elderly, the disabled, and the unemployed. While informal workers are recognised as important for waste management in the majority of cities of the Global South, their activities are generally labour-intensive, low-tech, low-paid, often managed autonomously or in the family (Dias, 2012; Taiwo, 2011; Wilson et al., 2012). They could be perceived as 'victims' of globalisation, bad jobs, modernization and economic liberalization processes. On the other hand, some perceive waste pickers as 'offenders'. Especially local authorities and private waste management companies often have a negative attitude towards the informal waste pickers and either neglect or repress them. They are considered incompatible with the increasingly standardised image of the modern city (Patwary et al., 2011; Sassen, 2014).

These representations as either victims or offenders are questioned (at least partially) by the collective actions promoted by non-governmental organisations (NGOs), trade unions and other community-based initiatives (Birkbeck, 1978; Medina, 2007; Schurman and Eaton, 2012). However, it remains fairly unclear how waste pickers are able to organise a 'collective voice' in these circumstances. The dominant stereotypes about waste pickers explain neither the nature of their work practices nor their interactions with other actors in waste management. To move beyond a mere victimization of the urban poor or a one sided romantic image of their resilience, this article combines a victimology perspective with a sociological analysis of the informal economy. By merging these two perspectives we pay attention to the work practices, the attempts to organise the waste pickers' actions 
collectively and to their relations with other social actors. This article continues by analysing the role of waste pickers based on the findings of two case studies conducted in Porto Alegre (Brazil) and Accra (Ghana).

\section{Waste pickers in Porto Alegre (Brazil)}

In Brazil around one million people subsist by relying on garbage collection. Waste pickers (catadores, in Brazilian-Portuguese) are present in 37 per cent of Brazilian state capitals and in 68 per cent of cities with more than 50,000 inhabitants. In 2010 the Federal Government's National Solid Waste Policy was approved, which promotes recycling practices and recognises the role of informal waste pickers. Despite this legislative change, the amount of collected urban waste is still generally low (2 per cent in 2003; 12 per cent in 2012) (Waldman, 2008; CEMPRE data).

In Porto Alegre, the capital of one of the richest Brazilian states, the Rio Grande do Sul, around 6,000 catadores operate in the urban area. This metropolitan area, with more than two billion inhabitants, has developed public waste disposal services since the early 1990s. The service is run by the Municipal Waste Management Department (Departamento Municipal de Limpeza Urbana, DMLU). Before 1990, waste was indiscriminately deposited in open-air dumps (the so-called lixoes). Because of their harmful effect on the environment and the human misery associated with them, the city administration proclaimed them a 'public calamity' when the sorted waste disposal service began. This made recyclable refuse an important and accessible source of economic sustenance for many workers who had been expelled from the formal economy after the liberalization and reorganization of the Brazilian economy (Pochmann, 2008). The shift from a waste recycling policy with mere environmental benefits to one with the potential to reduce urban unemployment and social fragmentation was neither automatic nor swift. The interaction between local authorities and informal waste pickers was characterized by periods of repression, neglect, competition and cooperation.

Waste pickers can be divided in four types: (1) carrinheiros: waste pickers who work individually collecting refuse with handcarts; (2) carroceiros: waste pickers who work individually collecting garbage with rickety horse-drawn wagons; (3) associations or cooperatives of waste pickers; 
and (4) middlemen (atravessadores), who buy recyclable materials from garbage collectors and resell them in bigger quantities to larger-scale middlemen or directly to firms that process waste for reuse in production. Formal actors complete the chain: the DMLU and the private firms. Carroceiros and carrinheiros are informal economic actors who operate as own-account workers and have very variable daily earnings. Generally, more material collected means higher profits although a carrinheiro earns R $\$ 240$ a month on an average while a carroceiro can earn up to R\$ 600 (the legal minimum wage at the time of the fieldwork was $\mathrm{R} \$ 260$ per month). The factors that push people into waste picking are basically economic. The occupational trajectories of some waste pickers show they often had previous 'formal' jobs in the manufacture or commerce sectors and had a decent standard of living. They were not born into poverty, but ended up in working situations with work deficits (ILO, 2007).

Waste pickers provide a flexible service, accepting unsorted waste and adjusting their pick-up routes according to the needs of their 'suppliers'. This is in contrast to the rigidity of the official waste disposal service where the end user has to comply with the requirements set by the service provider. In order to reduce the risks of the recyclable waste market, most of the carroceiros and carrinheiros have built a network of regular suppliers, i.e. citizens or owners of shops, restaurants, bars or offices that decided to give their sorted waste to the informal waste pickers instead of to the formal ones. These immaterial resources deriving from daily social relations seem to be decisive in ensuring the existence and reproduction of their work practices, although sometimes this form of social capital (Coleman, 1990) may turn into constraints and strengthen social segregation of waste pickers. For instance, carroceiros and carrinheiros frequently depended on a single middleman. This worker uses simple devices to weigh the materials and reduce them in volume, afterwards selling to larger-scale middlemen or recycling firms. In order to acquire large quantities of solid urban waste and reduce the costs of quality control, middlemen count on a significant number of carrinheiros, to whom they loan handcarts on the condition that they do not sell to other middlemen. This relationship of economic dependence is strengthened further because middlemen regularly grant credit to waste pickers and provide a place for catadores to sort their loads, mend their handcarts and in many cases, get some 
sleep. The middlemen's role is crucial because these small-scale entrepreneurs are the main buyers of collected recyclable materials. In this production chain, middlemen thus connect the informal and the formal part of the economy. As the recyclable material passes through their hands, it changes from a source of subsistence for the informal waste pickers to a source of economic profit for the middlemen. Therefore, waste assumes different values throughout this process of collecting, dismantling and sorting.

The fieldwork has highlighted that waste pickers are crucial for urban waste management, performing collecting, dismantling and sorting actions that produce value. However, their economically weak position and social stigma considerably impede them to capitalize on this. Forms of association have therefore become increasingly viable alternatives for individual work, providing opportunities for waste pickers to strengthen their position in the waste management chain. In 2004, in Porto Alegre metropolitan area there were 13 waste pickers' associations and cooperatives employing around 700 people. The fieldwork demonstrated an 'associational diversity' that varies depending on the associations' origins, organisational resources, demands, interests and purpose. Based on the latter, waste pickers' associations in Porto Alegre fall in two broad categories: (1) 'inside-oriented' associations, with an original purpose of protest, basically focused on self-regulation in order to improve the allocation of internal tasks, the working conditions and to reach (albeit small) economic targets. They focus on practices aimed at reinforcing self-esteem of waste pickers and monitoring and sanctioning opportunistic behaviours inside each group; (2) 'outside-oriented' associations, which have more general goals such access to collective benefits that ensure a minimum of wellbeing despite low income.

For instance, the Centro de Educação Ambiental (CEA) association (Environment Education Center) was set up to deal with the precarious living conditions of many people who live in Vila Pinto, one of the large settlements that arose following illegal occupations of land surrounding the centre of Porto Alegre. Drug traffickers controlled the entire community through intimidation and the use of force. They used the women - who spent most of the day at home - as unwilling minders of their drugs and weapons. Eulina, the female founder of the CEA, aimed to counter the existing dynamics between 
the local community and crime organizations by founding a women-only recycling association. This gave local women a good reason not to stay at home all day, providing them with an economic alternative to collaborating with the drug traffickers, albeit a quantitatively inferior one. The CEA also provided a cultural centre with courses in Portuguese, computer skills, music, theatre, and crafts. Most other associations are less organised than the CEA, but membership generally gives access to some 'social benefits'. For instance, members of the Novo Cidadão association, which was created to employ the homeless, receive part of their wage when they are absent from work due to illness or other unforeseen events, and have working hours which allow time to be devoted to other things as well. Moreover, for the members of some waste pickers' associations it is easier to participate in training courses organised by NGOs operating in the urban area or by the DMLU.

Associations seem to grant the waste pickers a series of 'close protections' (Castel, 2004), which, even though minimal and segmented, are entirely absent for informal own-account workers. Some grassroots organisations have even gained importance beyond the mere economic. Women-only associations (e.g. CEA) supplement small family incomes through earning, but more importantly are a source of social emancipation. Members have a dense network of social relations, based on trust and reciprocal support, that are fundamental to protect them from exploitation. The social function greatly outweighs the economic benefit.

The 'outside-oriented' associations are in a constant - although often difficult - dialogue with other actors in the community. One of the results of this dialogue is the Federation of Rio Grande do Sul Waste Pickers (Federação das Associações dos Recicladores de Resíduos Solídos do Rio Grande do Sul, FARRGS), a diverse and less exclusive collective organisation representing waste pickers in the region. Despite many problems due to representation issues, and different attitudes within the federation, FARRGS has become an interlocutor recognised by the local public authorities and by formal waste management. In Porto Alegre, such recognition has brought greater legitimisation to the activities undertaken by the waste pickers' associations, now an effective means for the informal workers both to interface with the local public authorities and to assert the waste pickers' role in waste management. Although this process of reciprocal recognition remains challenging, the local public 
authorities have delegated some responsibilities to the waste pickers' associations. In this way, they have partially reinforced their bargaining position with industry and government, although social and economic dependence on the middlemen remains. Besides representing and protecting the interests of its members, they (informally) cooperate with the public actor, strengthening their position in the waste management chain while at the same time weakening the social stigma and the unwarranted stereotypes about waste pickers.

\section{Waste pickers in Accra (Ghana)}

Like other countries in Sub-Sahara Africa both Ghana's population growth and its growing urbanization have resulted in increased waste generation (Harsch, 2001; Oteng-Ababio, Arguello and Gabbay, 2013). With a population of about 1.6 million, urban waste management is a serious challenge for the Ghanaian capital of Accra. Especially in the parts of the city with narrow and unpaved roads, where settlements came about largely unplanned, it can be challenging to collect the waste with vehicles. Waste from those parts of the city is often collected on handcarts and then brought to collection areas: 'The poor state of waste management is not only an engineering problem. It also has much to do with rapid urbanization, poor financial capacity, low technical capacity for planning and management and above all, lax and weak enforcement of environmental regulations $[\ldots]$ ' (Oteng-Ababio, 2011, p. 99).

Accra does not have proper landfills, but there are several areas in the metropolis where waste is collected, dismantled and burned or dumped. One of those is the Agbogbloshie neighbourhood, built on the shores of the Korle Lagoon, close to the slums, and often referred to as 'Sodom and Gomorra' because of its harsh living conditions and the presence of the dumpsite.

Formal waste collection in Accra is largely in the hands of private firms or public-private partnerships, but the informal share of waste collection is considerable. Informal employment is a sole source of livelihood for many. Indeed, similar to the Porto Alegre case, in Accra the informal activities of collecting, dismantling and sorting waste developed by waste pickers, buyers, traders and small- 
scale enterprises have a crucial role in waste management, representing the link between local communities and the formal waste sector.

Moreover, in this case, the repair, refurbishment, dismantling and recycling of second-hand electrical and electronic equipment (EEE) are very important. Second-hand television sets, computers, mobile phone (batteries) and other electronic components are sold on practically every street corner, with buyers prepared to purchase even untested and non-working items. The informal repair, refurbishment, collection and dismantling of discarded and second hand electronics is estimated to be the sole source of livelihood for up to 2 per cent of the Ghanaian population. These informal workers are wary of the term e-waste, because in many cases these 'used goods' are the only guarantee of livelihood (Prakash and Manhart, 2010). Ghanaian electronics imports also help to bridge the digital divide, allowing people to catch up with global developments in knowledge and communication.

This context is characterised by a chain of informal workers operating in waste management, from scrap collectors, repairers and dismantlers, and even organised crime groups (Article reference removed for peer review). In particular the informal waste collection is referred to as khaya bolas, i.e. people who collect waste from residencies to bring them in bags, baskets or on carts to dump sites or containers (similar to Porto Alegre). Many residents and businesses prefer paying a fee to these waste pickers rather than making use of the formally assigned collectors. Again, as in the Porto Alegre case, the service supplied by the informal waste pickers seems to be characterised by high flexibility.

Amongst the waste collectors there are some who sort the waste for recyclables to sell. The daily work practices of collecting, disassembly, dismantling and sorting done by waste pickers is a significant value creation process: they collect waste and e-waste in the streets, dwellings, offices and, in the case of e-waste, they dismantle electronic devices and sort valuable and non-valuable components. Repair, refurbishing, reselling, recycling and dismantling of electronics also happens in small workshops, which are supplied by informal collectors (hawkers, peddlers and individual vendors). Khaya bolas usually deliver their collected waste to middlemen who collect particular types of recyclables such as metal, plastic, or even mother boards (Oduro-Kwateng, 2011). 
The fieldwork in Accra has shown that waste management involves various formal and informal social actors in a chain in which waste pickers and middlemen have crucial roles, similar to the case of Porto Alegre. Waste pickers have many responsibilities in collecting, dismantling and sorting urban waste, while the middlemen perform an important role bridging formal and informal parts of the chain. In this urban context they are especially interested in buying motherboards or other valuable electronics components from waste pickers. Middlemen usually sell to bigger dealers guaranteeing the inflow of metals into recycling facilities with its increasing demand for secondary raw materials used in production.

Waste pickers represent the weakest link of the chain from an economic point of view, also in the Accra case. They might be paid four times less than the international market value and their working conditions are bad in many respects: waste pickers generally work and live in highly polluted environments, without any form of protection, and have no access to social benefits.

Although Ghana, like many other West African countries, has signed the international conventions on waste transports or about guaranteeing a healthy and safe environment for its citizens, these conventions are not transposed into national legislation. The institutional framework (or lack thereof) contributes to the spread of 'unregulated' import of e-waste and other types of waste (e.g. tyres). A law aimed to criminalize e-waste transports has been prepared by policy makers (i.e. the Ghanaian Environmental Protection Agency and the Ministry of the Environment), but it has been difficult to get this through Parliament because import taxes on imported second hand electronics (although often e-waste in practice) are an improtant source of revenue. Moreover, the digital divide has created a hunger for technology in developing countries that was partially fed by the import of ewaste from more economically advanced countries, and because the e-goods discarded by industrialised countries provide a source of livelihood for many waste pickers (Mathews, Ribeiro and Vega, 2012; Pellow, 2007; UNODC, 2009).

The environmental consequences are severe. Inadequate treatment of waste, especially hazardous waste like discarded electronics, can have detrimental effects for environmental and human health as well as for the economy (Sepulveda et al., 2010). In Ghana, as well as in many other Western African 
countries, adults and children go through the heaps of dumped electronic and electrical equipment in search of valuable materials, often barehanded and dismantle them without protective equipment. As witnessed in Agbogbloshie, many devices or cables are simply burned to remove the plastic casing and collect the metals. In this scenario vulnerable groups are also those most likely to suffer, because they have a bigger chance of working or living near the polluting factories or landfills. Those most severely harmed by the burning and dumping are the informal workers at the Agbogbloshie dump site and those that live in the nearby slums. These constitute a minority group who travelled to Accra from the North of Ghana in search of alternative sources of income: many of them are children and teenagers who travelled to Accra to provide income for themselves or for their families back home. As a NGO representative explained, many of the waste pickers, often minors, work at Agbogbloshie for three to five years and then return to their families in the North of Ghana, because their deteriorated health makes it impossible to work. This differential victimisation occurs mainly due to differences in cultural capital and in awareness about the harmful effect of working and living in a highly polluted environment. Also the social consequences are particularly dire. Despite that e-waste management is the unique source of income for many waste pickers, it causes many youngsters to drop out of school since they are attracted to working in this field. Even though education gives them better job prospects in the long run, they prefer waste picking because it does not require large investments before income earned.

Notwithstanding their bad working conditions and their dependent position in the waste management chain, many waste pickers in Accra believe to be able to improve both environmental and labour standards: 'We are moving away from the one-sided bad story, because a lot of progress has been made' (Jeff, informal metal scrap dealer). Improvements seem to be more viable when waste pickers act in collectively ways. Ghanaian NGOs - often supported by international organisations have tried to involve informal waste pickers, organising them in associations, as well as reaching out to recyclers for support. This for instance involves teaching Agbogbloshie boys how to remove the plastic from cables rather than burning the cables to get to the copper. There are even small-scale upcycling activities which use the collected recyclables to craft new products (for instance, metal is used 
for cooking or baking equipment). Involving the informal collection and dismantling sector and teaching them how to recycle environmental and health friendly prevents harm. Moreover, informal waste pickers are considered to be very effective in collecting and dismantling waste and this way they are empowered to help solve Accra's waste management problem.

\section{Waste pickers in the Global South: crucial for waste management and marginal for the labour market}

Recent studies have made macro-level comparisons of the informal economy in different countries, analysing the size and the nature of the informal economy in each country as well as how it relates to gross domestic product (GDP) and employment. At micro-level many single case studies on specific examples of informal economy have been conducted (for instance, Boels, 2014; Mahdavi, 2013; Thieme, 2015), but the attempts to compare several case studies are rare. This article contributes to the growing body of studies on micro-characteristics of informal work, developing a dialogue between two case studies on waste pickers' activities in two different cities (Accra and Porto Alegre). The cases differed in terms of cultural, economic and institutional contexts, as well as organisation of the municipal solid waste management and labour market. Despite these differences, our analysis has pointed to several similarities in the role of these waste pickers in waste management, in some of their work practices, and in their interaction with the formal labour market.

The informal waste pickers play an important role in waste management that cannot easily be taken up by the formal waste management system. Sometimes, these informal workers provide services in the absence of (effective) publically organized waste management, as was previously demonstrated for Nairobi, Kenya (Thieme, 2010). Due to their effectiveness, efficiency and flexibility, waste pickers are integral to the waste collection activities. They are complementary to the public or private waste disposal services. Moreover, their efficiency in collecting waste - and thus secondary raw materials - is essential in times of increasingly scarce natural resources. This also holds potential to avoid the environmental hazards resulting from inadequate waste disposal, although admittedly a lot or progress can still be made with regard to recycling techniques and protective equipment. 
Waste pickers are crucial in the 'revalorization' process of waste in which it changes from a useless residue to an economic resource. They are part of a supply chain that involves formal and informal economic actors, at local, national and international level. An analysis of the urban waste management process therefore requires paying attention to the 'bargaining power' of each actor through the supply chain. In both case studies, the middlemen - who often are informal entrepreneurs seem to be a crucial link, connecting informal waste pickers to the formal industry. The sorted waste changes its economic value in the hands of these middlemen. It is a source of subsistence for the informal waste pickers as well as of profit in the economic exchanges among middlemen and with industry. The relationship between these middlemen and waste pickers can be one of cooperation and even support, but has also shown to be fragile in face of volatile values of secondary raw materials.

Moreover, the relational networks among waste pickers and their suppliers ensure the continued existence of informal economic practices. The use of these forms of social capital can produce positive as well as negative effects for the informal waste pickers. In line with one of the key definitions of social capital (Putnam, 1993), the fieldwork has shown forms of 'bonding social capital' such as in the interaction between waste pickers and middlemen, and forms of 'bridging social capital' such as by means of the associations of waste pickers.

The waste pickers' universe is very fragmented in terms of social recognition and working conditions. Our fieldwork has shown that the informal waste pickers are not passive underdogs, but that they have developed strategies to improve their economic activity. The choice to work in the informal economy might actually be an empowered choice rather than the result of sheer necessity to work informally due to a lack of formal employment opportunities, as has been demonstrated for other parts of the informal economy (De Soto, 1989; Mahdavi, 2013). However, especially the case of Accra has shown that for some informal workers, waste picking is still a last and only resort. For them, waste picking is a way to survive but can also be very harmful.

In these scenarios grassroots organisations provide opportunities for waste pickers to improve their image and to build a 'social safety net', against for instance fluctuating prices for recyclables or customer unwillingness to pay. Collective initiatives of waste pickers to change their unfavourable 
position can produce innovative forms of legitimization of their work and their position in urban waste management. Taking on informal waste work while still organizing themselves collectively strikes a balance between keeping their autonomy and providing better income guarantees, albeit often still precarious and incomplete.

This article has shown the multidimensionality of the waste pickers' phenomenon. We demonstrated that informal waste pickers play a crucial role in waste management in both cities, despite differing economic, social and institutional contexts. The informal waste pickers are integral to the waste management system and take advantage of the under-utilized opportunities of waste as a source of income. Moreover, they exemplify the multiple connections between informal and formal parts of the waste economy. Our cases studies have illustrated the intricate dynamics of the work of waste pickers and their interactions with customers, middlemen and other actors in waste management. However, waste pickers also remain in an economically disadvantaged position that excludes them from the formal labour market. This increases the risk of them becoming a 'victim' of the economic globalization process. Faced with these challenges, they develop creative solutions to guarantee their livelihood and gain 'collective voice'. The duality of the informal waste pickers thus remains. Therefore, it is important for future research to further examine the role of waste pickers in urban waste management and their attempts to collectively organise their interests.

Moreover, it is essential for policies on informal economy, waste management and environment to take the intricate dynamics of the work of waste pickers and their interactions into account and to embrace its multidimensionality. Policies to provide informal workers with opportunities to develop their expertise into a formal business do not always serve the rights of the most vulnerable and might even have counterproductive effects from an environmental or waste management point of view. Development or poverty alleviation programmes do not always sufficiently take into account the cultural and structural specificities of the Global South nor the complex interactions between formality and informality. Also in developing formal waste management systems, it is crucial to take into account the unique traits of informal waste pickers and their service to the community. 


\section{References}

Agarwala, R. (2013), Informal Labor, Formal Politics and Dignified Discontent in India, Cambridge University Press, Cambridge.

Bacchetta, M., Ekkehard, E., and Bustamante, J. (Eds.) (2009), Globalization and Informal Jobs in Developing Countries, ILO and WTO, Geneva.

Baker, E., Bournay, E., Harayama, A., and Rekacewicz, P. (2004), "Vital Waste Graphics", Basel Convention, Grid Arendal, UNEP, DEWA Europe.

Barley, S.R., and Kunda, G. (2001), "Bringing Work Back In”, in Organization Science, Vol. 12, No. 1, pp. 76-95.

Birkbeck, C. (1978), "Self-employed proletarians in an informal factory: The case of Cali's garbage dump", in World Development, Vol. 6, No. 9-10, pp. 1173-1185.

Boels, D. (2014), "It's better than stealing: informal street selling in Brussels", in International Journal of Sociology and Social Policy, Vol. 34, No. 9/10, pp. 670-693.

Calafate-Faria, F. (2013), Countercycling: An Ethnographic Study of Waste, Recycling, and WastePickers in Curitiba, Brazil, PhD Thesis, Goldsmiths, University of London, London.

Castel, R. (2004), L'insicurezza sociale, Einaudi, Torino.

Castells, M., and Portes, A. (1989), "World Underneath: The Origins, Dynamics, and Effects of the Informal Economy" in Portes, A., Castells, M., and Benton, A.L. (Eds.), The Informal Economy: Studies in Advanced and Less Developed Countries, The Johns Hopkins University Press, Baltimore, pp. 11-37.

Centeno, M.A., and Portes, A. (2006), "The Informal Economy in the Shadow of the State" in Fernández-Kelly P. and Shefner J. (Eds.), Out of the Shadow, Pennsylvania University Press, Pennsylvania, pp. 23-49.

Charmes, J. (2012), "The Informal Economy Worldwide: Trends and Characteristics”, in Margin-The Journal of Applied Economic Research, Vol. 6, No. 2, pp. 103-132. 
Chen, M.A. (2006), "Rethinking the Informal Economy: Linkages with the Formal Economy and the Formal Regulatory Environment”, in Guha-Khasnobis, B., Kanbur, R. and Ostrom, E. (Eds.), Linking the Formal and Informal Economy, Oxford University Press, New York, pp. 75-93.

Coleman, J. (1990), Foundations of Social Theory, The Belknap Press of Harvard University Press, Cambridge.

De Soto, H. (1989), The Other Path, Basic Book, New York.

Dias, S. (2012), "Not to be taken for granted: what informal waste pickers offer the urban economy", in The Global Urbanist, http://globalurbanist.com/2012/11/27/waste-pickers.

Feige, E.L. (1990), "Defining and Estimating Underground and Informal Economies: The New Institutional Economics Approach”, in World Development, Vol. 18, No. 7, pp. 989-1002.

Flyvbjerg, B. (2006), "Five Misunderstandings About Case-Study Research", in Qualitative Inquiry, Vol. 12, No. 2, pp. 219-245.

Gallin, D. (2001), "Propositions on Trade Unions and Informal Employment in Times of Globalization" in Antipode, Vol. 33, No. 3, pp. 531-549.

Gasparini, L. and Tornarolli, L. (2006), Labor Informality in Latin America and the Caribbean: Patterns and Trends from Household Survey Microdata, World Bank, Washington DC.

Godfrey, P. (2011), "Toward a Theory of the Informal Economy", in The Academy of Management Annals, Vol. 5, No. 1, pp. 231-277.

Godfrey, P. (2015), Management, Society, and the Informal Economy, Routledge, London.

Guha-Khasnobis, Kanbur, R., and Ostrom, E. (Eds.) (2006), Linking the Formal and Informal Economy, Oxford University Press, New York.

Harsch, E. (2001), “African cities under strain: Initiatives to improve housing, services, security and governance", in Africa Recovery, Vol. 15, No. 1-2, pp. 30-44.

Hart, K. (1973), "Informal Income Opportunities and Urban Employment in Ghana”, in Journal of Modern African Studies, Vol. 11, No. 1, pp. 61-89.

Hart, K. (2010), “Informal economy”, In Hart, K., Laville, J.L. and Cattani, A.D. (Eds.), The Human Economy, Polity Press, Cambridge, UK. 
Hoornweg, D., and Bhada-Tata, P. (2012), "What a Waste. A Global Review of Solid Waste Management”, Urban Development Series Knowledge Papers, World Bank, Washington.

ILO (1972), Employment, Income, and Equality. A Strategy for Increasing Productive Employment in Kenya, ILO, Geneva.

ILO (2002), Decent Work and the Informal Economy, Report VI, ILO, Geneva.

ILO (2007), The informal economy, Report of the Committee on Employment and Social Policy, ILO, Geneva.

ILO (2015), Recommendation 204 Concerning the Transition from the Informal to the Formal Economy, ILO, Geneva.

Kanbur, R. (2014), “Informality: Causes, Consequences and Policy Responses”, Working Paper n. 18, Charles H. Dyson School of Applied Economics and Management, Cornell University, Ithaca, New York.

La Porta, R. and Shleifer, A. (2014), "Informality and Development" in Journal of Economic Perspectives, Vol. 28, No. 3, pp. 109-126.

Latouche, S. (1993), Il pianeta dei naufraghi, Bollati Boringhieri, Torino.

Lewis, W.A. (1954), "Economic Development with Unlimited Supplies of Labour”, in Manchester School, Vol. 22, pp. 139-191.

Lundgren, K. (2012), The Global Impact of e-waste, ILO, Geneva.

Mahdavi, P. (2013), "Gender, labour and the law: the nexus of domestic work, human trafficking and the informal economy in the United Arab Emirates", in Global Networks, Vol. 13, No. 4, pp. 425440.

Mathews, G., Ribeiro, R., and Vega, C. (Eds.) (2012), Globalization from below. The world's other economy, Routledge, London.

Medina, M. (2007), The World's Scavengers: Salvaging for Sustainable Consumption and Production, AltaMira Press, Lanham, MD. 
Oduro-Kwateng, S. (2011), Private sector involvement in urban solid waste collection. Performance, capacity and regulation in five cities in Ghana, CRC Press/Balkema Taylor and Francis Group, Leiden.

OECD (2009), Is Informal Normal? Towards more and better jobs in developing countries, OECD Publishing, Paris.

Oteng-Ababio, M. (2011), "The role of the informal sector in solid waste management in the Gama, Ghana: Challenges and opportunities", in Tijdschrift voor Economische en Sociale Geografie, Vol. 103, No. 4, pp. 412-425.

Oteng-Ababio, M., Arguello, J., and Gabbay, O. (2013), "Solid waste management in African cities: Sorting the facts from the fads in Accra, Ghana", in Habitat International, Vol. 39, pp. 96-104.

Patwary M.A., O’Hare W.T., Sarker M.H. (2011), “Assessment of occupational and environmental safety associated with medical waste disposal in developing countries: a qualitative approach", in Safety Science, Vol. 49, No. 8, pp. 1200-1207.

Peattie, L. (2001), “Theorizing planning: Some comments on Flyvbjerg’s Rationality and power”, in International Planning Studies, Vol. 6, No. 3, pp. 257-262.

Pellow, D. (2007), Resisting global toxics: Transnational movements for Environmental Justice, MIT Press, Cambridge MA.

Pochmann, M. (2008), O emprego no desenvolvimento da nação, Boitempo, São Paulo.

Polanyi, K. (1977), The livelihood of man, Academic Press, New York.

Portes, A. and Schauffler, R. (1993), "Competing Perspectives on the Latin American Informal Sector", in Population and Development Review, Vol. 19, No. 1, pp. 33-60.

Portes, A., Castells, M., and Benton, A.L. (Eds.) (1989), The Informal Economy: Studies in Advanced and Less Developed Countries, The Johns Hopkins University Press, Baltimore.

Prahalad, C. and Hammond, A. (2002), "Serving the world's poor, profitably", in Harvard Business Review, September issue, pp. 48-57.

Prakash, S., and Manhart, A. (2010), Socio-economic assessment and feasibility study on sustainable e-waste management in Ghana, Öko-Instutut e.V., Inspectorate of the Ministry of Housing, 
Spatial Planning and the Environment of the Netherlands (VROM-Inspectorate) and the Dutch Association for the Disposal of Metal and Electrical Products (NVMP), Freiburg.

Putnam, R. (1993), Making democracy work: civic tradition in modern Italy, Princeton University Press, Princeton.

Rakowski, C.A. (1994), "Convergence and divergence in the informal sector debate: A focus on Latin America”, in World Development, Vol. 22, No. 4, pp. 501-516.

Robinson, B.H. (2009), "E-waste: an assessment of global production and environmental impacts", in Science of the Total Environment, Vol. 408, No. 2, pp. 183-191.

Rosaldo, M. (2012), Scrapping for decent work: Colombian recycler cooperatives' struggles for social and economic inclusion, Paper presented at the International Sociological Association Forum: Social Justice and Democratization, August 2012, Buenos Aires, Argentina.

Sassen, S. (2007), A Sociology of Globalization, W.W. Norton and Company, New York.

Sassen, S. (2014), Expulsions. Brutality and Complexity in the Global Economy, Harvard University Press, London.

Schmoll, C., and Semi, G. (2013), "Shadow circuits: urban spaces and mobilities across the Mediterranean", in Identities: Global Studies in Culture and Power, Vol. 20, No. 4, pp. 377-392.

Schneider, F., and Enste, D. (2000), "Shadow economies: Size, causes, and consequences", in Journal of Economic Literature, No. XXXVIII, pp. 77-114.

Schneider, F., Buehn, A., and Montenegro, C. (2010), "New Estimates for the Shadow Economies all over the World", in International Economic Journal, Vol. 24, No. 4, pp. 443-461.

Schurman S.J., and Eaton A.E. (Eds.) (2012), Trade Union Organizing in the Informal Economy: A Review of the Literature on Organizing in Africa, Asia, Latin America, North America and Western, Central and Eastern Europe, Report to the Solidarity Center, Rutgers University.

Scott, A.J. (2012), A World in Emergence: Cities and Regions in the 21st Century, Edward Elgar, Cheltenham.

Sepúlveda, A., Schluep, M., Renaud, F., Streicher, M., Kuehr, R., Hagelüken, C., and Gerecke, A. (2010), "A review of the environmental fate and effects of hazardous substances released from 
electrical and electronic equipment during recycling: Examples from China and India", in Environmental Impact Assessment Review, Vol. 30, No. 1, pp. 28-41.

Taiwo, A.M. (2011), "Composting as a sustainable waste management technique in developing countries", in Journal of Environmental Science and Technology, Vol. 4, pp. 93-102.

Thieme, T. (2010), "Youth, waste and work in Mathare: whose business and whose politics?", in Environment \& Urbanization, Vol. 22, No. 2, pp. 333-352.

Thieme, T. (2013), “The hustle amongst youth entrepreneurs in Mathare's informal waste economy", in Journal of Eastern African Studies, Vol. 7, No. 3, pp. 389-412.

Thieme, T. (2015), "Turning hustlers into entrepreneurs, and social needs into market demands: Corporate-community encounters in Nairobi, Kenya", in Geoforum, Vol. 59, pp. 228-239.

UNODC (2009), Transnational trafficking and the rule of law in West-Africa: A threat assessment, United Nations Office on Drugs and Crime, Vienna.

Van Maanen, J.V. (1979), “The Self, the Situation, and the Rules of Interpersonal Relations", in Bennis W. et al., Essays in interpersonal dynamics, Homewood, Dorsey.

Waldman, M. (2008), "Reciclagem, preservação ambiental e o papel dos catadores no Brasil", Paper presented at the VI Simpósio Internacional de Qualidade Ambiental, Porto Alegre (May).

Williams, C.C. (2014), "Out of the shadows: a classification of economies by the size and character of their informal sector", in Work, Employment and Society, Vol. 28, No. 5, pp. 735-753.

Williams, C.C., Horodnic, I.A. and Windebank, J. (2015), "Explaining participation in the informal economy: An institutional incongruence perspective", in International Sociology, Vol. 30, No. 3, pp. 294-313.

Williams, C.C., Kedir, A., Nadin, S. and Vorley, T. (2013), "Evaluating the extent and nature of the informalization of employment relations in South-East Europe", in European Journal of Industrial Relations, Vol. 19, No. 2, pp. 91-107.

Wilson, D.C., Rodic, L., Scheinberg, A., Velis C.A., Alabaster, G. (2012), "Comparative analysis of solid waste management in 20 cities", in Waste Management \& Research, Vol. 30, No. 3, pp.237254. 
Wong, A.M. (2015), "Articulation of Informal Labour: Interrogating the E-waste Value Chain in Singapore and Malaysia", in Newsome, K., Taylor, P., Bair, J., Rainnie, A. (Eds.), Putting Labour in Its Place, Palgrave Macmillan, London. 